\title{
Student's Performance in Digital Electronic Design: A Comparison between Two Education Techniques, Project Based Learning and Micro-Learning
}

\author{
Diaeddeen Elmezoghi ${ }^{1}$, Can Doğan Vurdu ${ }^{2}$ \\ ${ }^{1}$ Material Science and Engineering Department, Institute of Science, Kastamonu University, Kastamonu, Turkey \\ ${ }^{2}$ Biomedical Engineering Department, Faculty of Engineering and Architecture, Kastamonu University, Kastamonu, Turkey
}

\begin{abstract}
In regard to the ongoing efforts to improve engineering education, this paper presents the experience in using of two education technology in separate in teaching digital electronic design subject in YuldormBeyazit university, and clarifies the difference in student performance factor in digital electronic design subject between two groupsof students learn the subject in the university in the aim of finding a new effective and instructive learning method, the first group learns the subject using micro leaning technique and the other group learns the subject by using project-based learning technique. The use of these techniques has had a good impact on student educationand the assessment of this study, shows the difference in applying Micro Learning technique in teaching digital electronic subject compared to applying Project-Based Learning technique.
\end{abstract}

Keywords: Student performance, Digital Electronics, Project Based Learning, Micro-learning Introduction, FPGA, Engineering Education

\section{Introduction}

Student performance is the extent to which a student has achieved his short or long-term educational goals. Cumulative grade point average "GPA" and completion of educational degrees, it is commonly measured through examinations or continuous assessments[1], and the performance improvement in teaching and learning is an important challenge for universities to improve their outputs, achieve the development and because of its significance as a field of scientific research. The universities Support studies and research in this area to boost their rank and to keep pace with the changes out of the class in real world, this target drove us to search in ways of making the learning of digital electronic design subject more effective, instructive and to improve student performance. The paper is a part of study named "Using Of Project-Based Learning and MicroLearning Technique and FPGA Technology in Teaching Digital Electronics Subject", presents the difference in performance factor in digital electronic design subject between two groups of students learning the subject. The main aim of study is to meet the growing need to improve digital electronic education methods for effective, fast and thorough learning process and in additional to enhance the performance of students as a result, To achieve that, we applied and examined two educational methods in teaching digital electronics subject on two undergraduate groups, Micro Learning technique on the first group, Project Based Learning on the second group with the instructive examples and attractive projects covered the course by using Field Programmable Gate Array "FPGA" technology. The course lectures divided in 3 theoretical hours and 2 lab hours, the developed instructive and attractive examples studied in the course by using FPGA technology and combined various hardware and software activities to make the learning of subject more attractive and beneficial. FPGA characteristics and Graphical Programming with Simulation Software examples are intuitive and powerful tools that enhance the interest of students in engineering and science studies, boost ability to update, and offer advantages to the students for many applications. FPGA are well-suited because of its advantages "flexible in use, reconfigurable to adapt for any new standards, can be programmed after manufacturing instead of being restricted to any predetermined hardware function, can be implemented to any logical function, allowed complexity in design, and for its graphical interface.

\section{Theoretical Background and Methods}

\section{Micro-learning model}

Micro-learning maybe defined as a process of subsequent, "short" learning activities[2], i.e. learning through interaction with micro-content objects in small timeframes[3, 4], the first model of study is learning digital electronics course applying (ML) Micro-learning technique, studying examples and projects of the study (attractive and instructive examples and projects) using FPGA. In this model the student aims to benefit from Micro-learning, and it is introduced with quite small learning pieces and activities for short term learning. This model is conducted in digital electronic course, second semester students, 2016 fall period (56 student) and we applied Microlearning technology in teaching this model to benefit from its characteristics and in additional to benefit from FPGA technology.

It is important in teaching digital electronic design to add large examples into digital electronic course parts by dividing them into small sub-blocks. Each sub block should take definite and measurable small time to address definite topic of digital electronics course, and must be designed in term of education to reach the advantage of Micro learning technique. The topics were shared to the students in computer images or text files, also the media of internet offered another choices and possibilities to help students in their work and played a significant role in learning processes. The course was attractive, instructive and

Volume 7 Issue 1, January 2018 


\section{International Journal of Science and Research (IJSR) \\ ISSN (Online): 2319-7064 \\ Index Copernicus Value (2016): 79.57 | Impact Factor (2015): 6.391}

completed with good results and in addition the performance was good.

\section{Project Based Learning model}

Project Based Learning technique in which learners actively explore actual problems [5], challenges and obtain a deeper understanding, Emerge learners in deep thinking while linking their learning in the school to the real world[6], and boost the learners to become independent learners[7]. Project Based Learning model is conducted in digital electronic course, second semester 2016 summer period (47 students). Also in this model, we used FPGA technology and applied Project Based Learning technique in teaching the subject to benefit from its characteristics by involving the students in projects attract and inspire them to achieve effective learning, ability to design projects, high performance, best results and to obtain deeper knowledge of the project they're studying. Projects were designed to cover the subject topics in a vision of project based learning PBL beginning from the way of introducing students to the project, achieving the need to know, Acquiring concern and initiating enquiring with specific entry event to challenge students and attract them to participate in the projects and attract them to work and stimulate them to ask and drive their questions[6].

Project based learning offered many choices for students to implement projects and select components in their ideas and the work in projects achieve the properties of inquiry and innovation, and continually there is a feedback and revision which make learning more meaningful[ $[8,9]$.

Finally, the students interacted with the course and they found the subject more attractive and instructive and their performance was very good.
The main projects in the study:

1) Factory project.

2) Clock project.

3) Calendar project.

4) CPU project.

And these projects were prepared in two versions with two levels of complexity.

- Version 1 (V1), it is a class work project it is a simple one; the students should execute this version in the class.

- Version 2 (V2), it is a home work project it is same to V1 in title and function but hard than V1, and it is considered as hard work.

The assessment were based on students Practical Activities (classwork, lab work and home assignments)

\section{Results}

In our study in assessing performance factor for the two models of study, we adopted measuring practical student's activities; therefore the comparison will rely on the marks of students, lab work and their assignments in home work.

According to that, we gave importance to the projects and examples of the study and they were prepared to cover all the curriculum and directed to achieve all the factors of the study, and after analyzing the data coming from (1)Version one activities (V1) "class work marks" and (2)Version two activities (V2) "assignments marks", we got next comparisons between the models of study, learning by using Project Based Learning technique model and learning by using Micro Learning technique model, shown in the figure 1 , table 1 shows The means of students marks in V1 activities and V2 activities, and table 2 shows t-test analysis which indicate significant difference between the means of the two models.

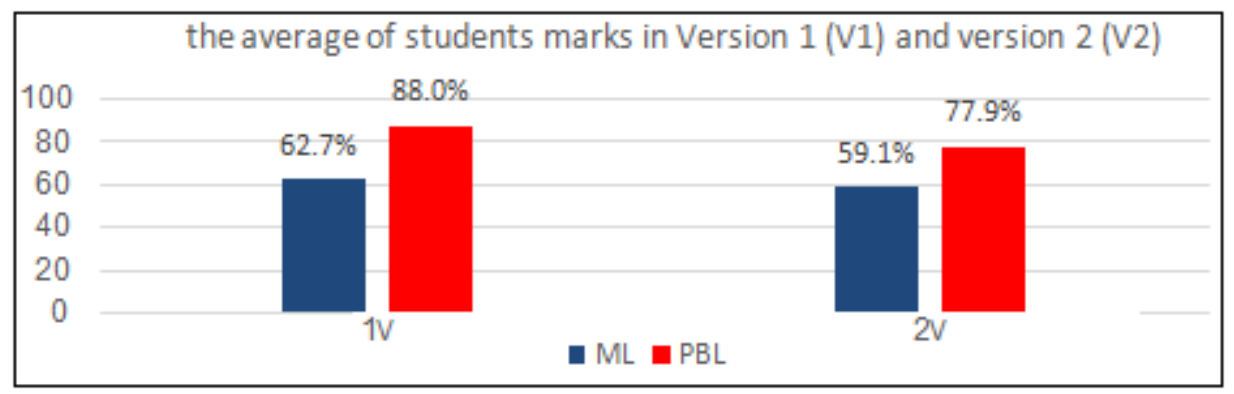

Figure 1: The average of students marks in Version 1 (V1) and version 2 (V2)

Table 1: The average of students marks in Version 1 (V1) and version 2 (V2)

\begin{tabular}{|c|c|c|c|c|c|}
\hline & ID & $\mathrm{N}$ & Mean & $\begin{array}{c}\text { Std. } \\
\text { Deviation }\end{array}$ & $\begin{array}{c}\text { Std. } \\
\text { Error Mean }\end{array}$ \\
\hline \multirow{2}{*}{ V1 } & PBL & 47 student & 88.0 & 12.8 & 1.9 \\
\cline { 2 - 6 } & ML & 56 student & 62.7 & 24.4 & 3.3 \\
\hline \multirow{2}{*}{ V2 } & PBL & 47 student & 77.9 & 24.1 & 3.5 \\
\cline { 2 - 6 } & ML & 56 student & 59.1 & 23.4 & 3.1 \\
\hline
\end{tabular}

Volume 7 Issue 1, January 2018 www.ijsr.net 
International Journal of Science and Research (IJSR)

ISSN (Online): 2319-7064

Index Copernicus Value (2016): 79.57 | Impact Factor (2015): 6.391

Table 2: Independent Samples Test

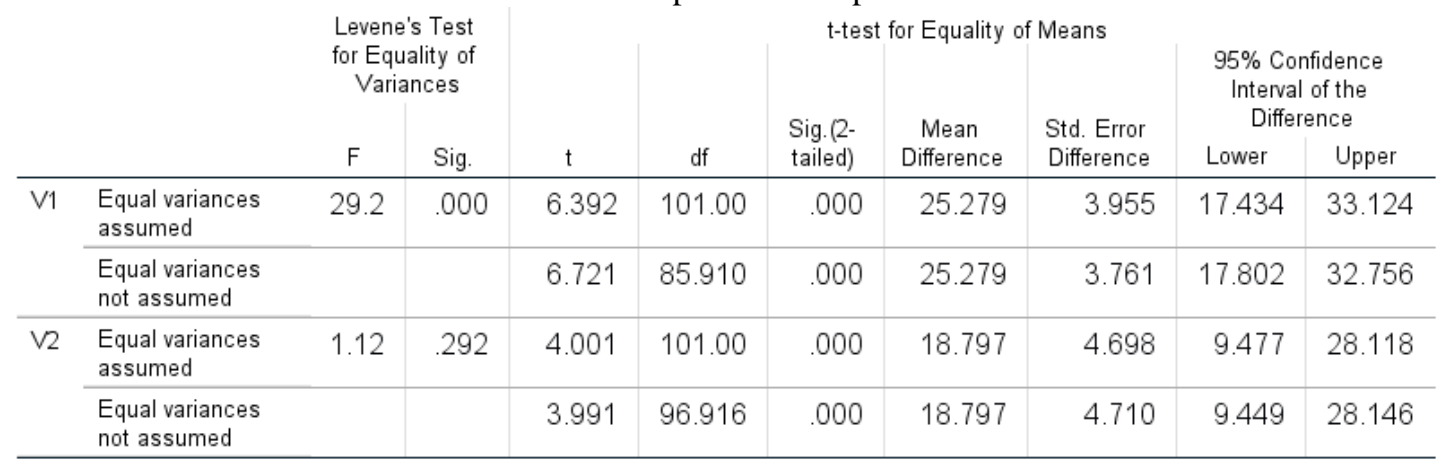

Since $\mathrm{p}<.0001$ is less than chosen significance level $\alpha=$ 0.05 , we can reject the null hypothesis, and conclude that the mean of performance factor (V1 and V2) for project based learning model and Micro learning is significantly different and based on the results, we can state the following:

Version 1

1) There was a significant difference in the mean of performance factor for version 1 (V1) between project based learning model and Micro learning model (t85.910 $=6.721, \mathrm{p}<.05)$.

2) The average performance factor for project based learning model version 1 (V1) was 25.3 degree greater than the average performance factor for micro learning.

Version 2

1) There was a significant difference in the mean of performance factor for version 2 (V2) between project based learning model and Micro learning model $(101.0=$ 4.001, $\mathrm{p}<.05)$.

2) The average performance factor for project based learning model version 2 (V2) was 18.8 degree greater than the average performance factor for micro learning.

\section{Conclusion}

The objective of this study was to examine the student performance in applying two different education techniques Project (Based Learning PBL and Micro-learning). The applying of Micro learning and Project based learning in teaching learning digital electronic design subject was good experience, and the performance of students in Practical work (the Activities of classwork, lab work and home assignments) when applying Project Based Learning on second group was the best in the subject which appears clearly in the response of students to projects and examples in the course which affected their marks.

\section{References}

[1] A. Ward, H. W. Stoker, and M. Murray-Ward, "Achievement and ability tests-Definition of the domain," Educational Measurement, vol. 2, pp. 2-5, 1996.

[2] M. J. Lee, C. Miller, and L. Newnham, "RSS and content syndication in higher education: subscribing to a new model of teaching and learning," Educational Media International, vol. 45, pp. 311-322, 2008.

[3] C. McLoughlin and M. J. Lee, "Pedagogy 2.0: critical challenges and responses," Web 2.0-Based E-Learning:
Applying Social Informatics for Tertiary Teaching: Applying Social Informatics for Tertiary Teaching, p. 43, 2010.

[4] M. I. F. Souza and S. F. do Amaral, "Educational microcontent for mobile learning virtual environments," Creative Education, vol. 5, p. 672, 2014.

[5] S. Bell, "Project-based learning for the 21st century: Skills for the future," The Clearing House, vol. 83, pp. 39-43, 2010.

[6] P. C. Blumenfeld, E. Soloway, R. W. Marx, J. S. Krajcik, M. Guzdial, and A. Palincsar, "Motivating project-based learning: Sustaining the doing, supporting the learning," Educational psychologist, vol. 26, pp. 369-398, 1991.

[7] H. A. Hadim and S. K. Esche, "Enhancing the engineering curriculum through project-based learning," in Frontiers in Education, 2002. FIE 2002. 32nd Annual, 2002, pp. F3F-F3F.

[8] J. Larmer and J. R. Mergendoller, "Seven essentials for project-based learning," Educational leadership, vol. 68, pp. 34-37, 2010.

[9] J. L. Polman, Designing Project-Based Science: Connecting Learners through Guided Inquiry. Ways of Knowing in Science Series: ERIC, 2000.

Volume 7 Issue 1, January 2018

www.ijsr.net

Licensed Under Creative Commons Attribution CC BY 